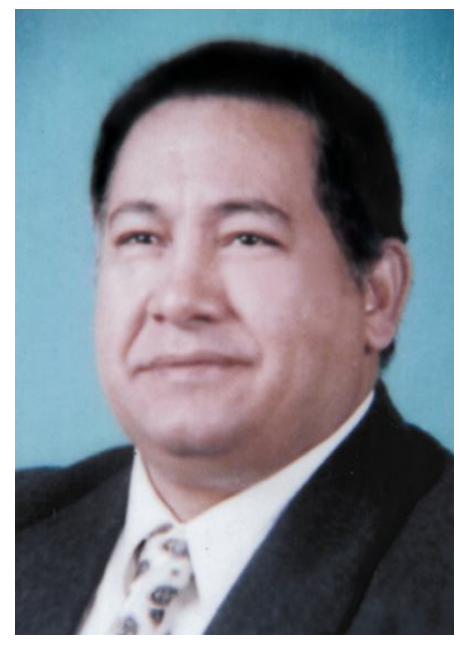

$$
\begin{aligned}
& \text { أ.د / جابر محهود هلبم } \\
& \text { العميد المؤسس لكلية ريـاض الأطفال } \\
& \text { جامعة المنصورة }
\end{aligned}
$$




\section{السيرِ الذانيّة}

\section{البيانات الشخصية :-}

• الاســـــــ : جابر محمود طلبه الكارف

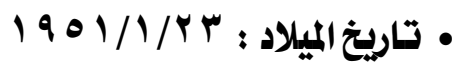

• الدرجة الوظيفة : أستاذ

• الحالة الاجتماعية : متزوج ويعول

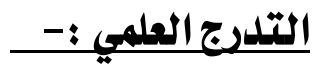

• بكـالوريوس عــوم وتربيـة ـ تــاريخ طبيعـي ـ كليـة التربيـة جامعـة المنـصورة -

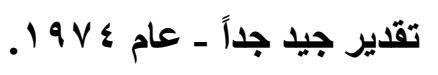

• دبلــوم خـاص فـي التربيـة ـ إدارة تعليميـة ـ كليـة التربيـة جامعـة المنـصورة

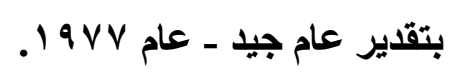

• ماجستير في التربيـة ـ ريـاض أطفـال ـ كليـة التربيـة جامعـة المنصورة - بتقدير

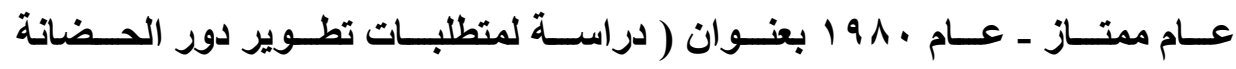

$$
\text { ورياض الأطفال في محافظة الدقهلية ) . }
$$

• دكتـوراه الفلـسفة في التربيـة ـ تربيـة الطفل ـ كليـة التربيـة جامعـة المنـصورة -

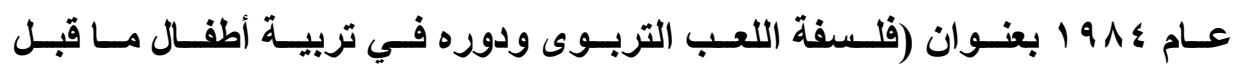

$$
\text { المدرسة ). }
$$




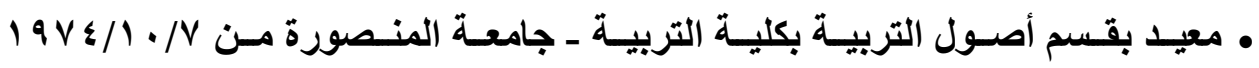

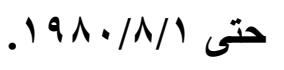

• مــدرس مـسـاعد بقـسم أصــول التربيـة بكليـة التربيـة ـ جامعـة المنـصورة مـن

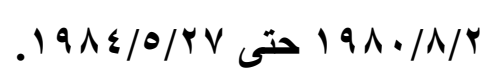

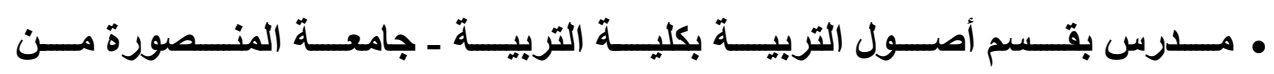

$$
\text { 1990/0/\% 19 19 19 19/0/\% }
$$

• أســتاذ مسساعد بقـسم أصــول التربيــة بكليــة التربيــة ـ جامعــة المنــصورة مــن

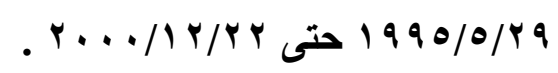

• أســتاذ تخــصص تربيــة طفـلـل بقـسم أصــول التربيــة بكليــة التربيــة ـ جامعــة

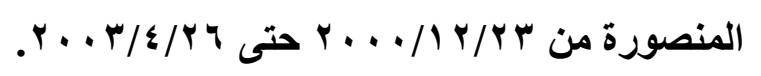

• أســتاذ تخــصص تربيــة طفـلـل بقـسم ريــاض الأطفــال بكليــة التربيــة ـ جامعــة

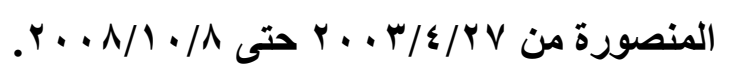

• أســتاذ تخـصص تربيــة الطفـل بقـسم العلـوم التربويــة بكليـة ريــاض الأطفــال ـ

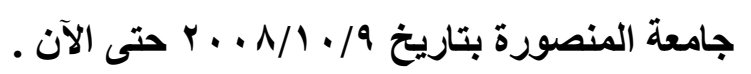

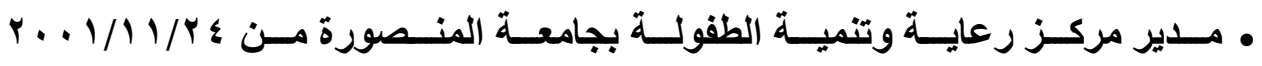

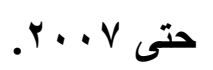

• رئسيس مجلـس قـسم ريــاض الأطفــال بكليــة التربيــة جامعــة المنــصورة مــن

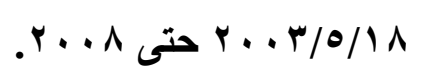


• نـلب سـيادته مديراً لمشروع تحسبن التعليم فـي الطفولــة المبكرة بـوزارة التربيـة

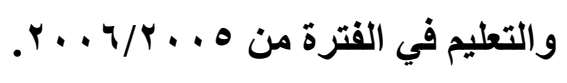

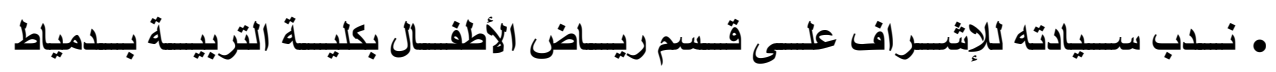

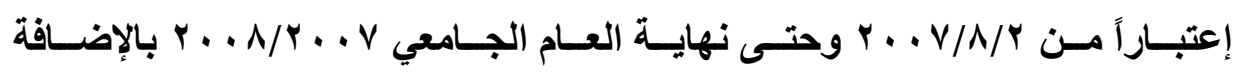

$$
\text { إلى عمله الأصلي. }
$$

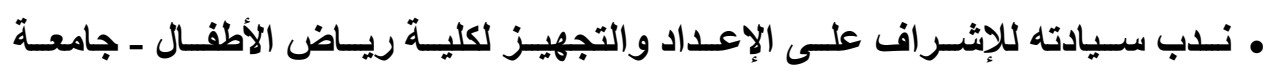

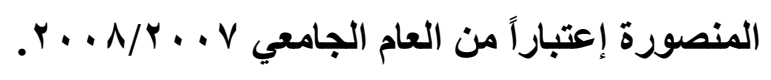

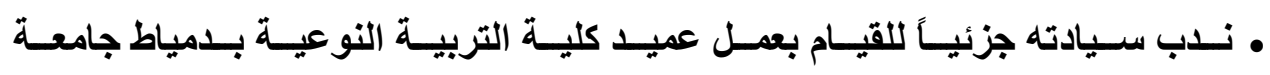

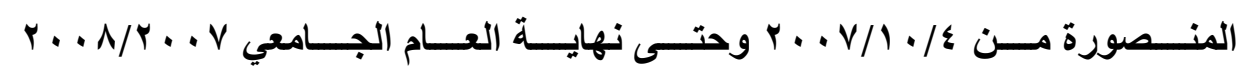
بالإضافة إلى عمله الأصلي .

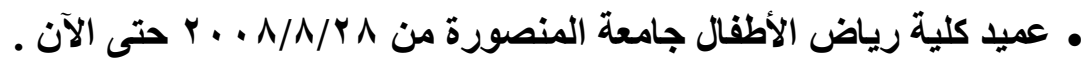

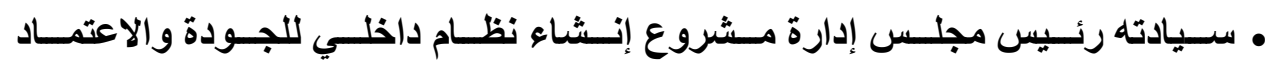

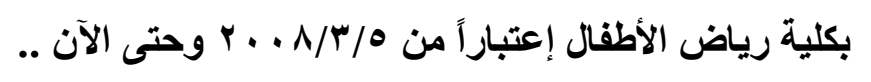

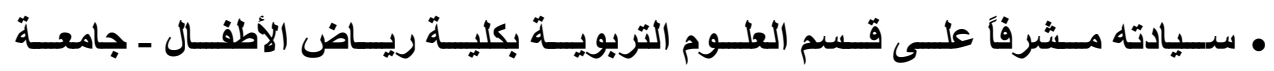

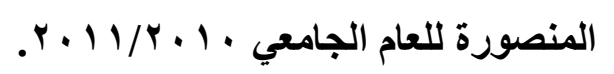

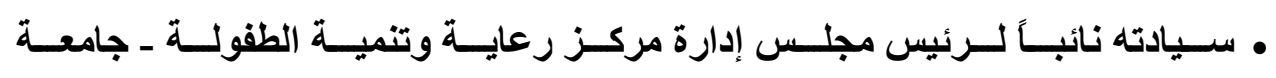

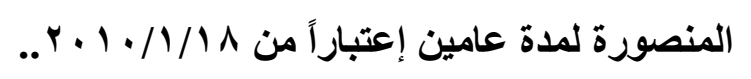

جهــة العمل

• قـسم العــوم التربويــة / كليــة ريسـاض الأطفــال / جامعـة المنـصورة ـ تــاريخ

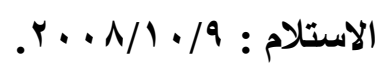




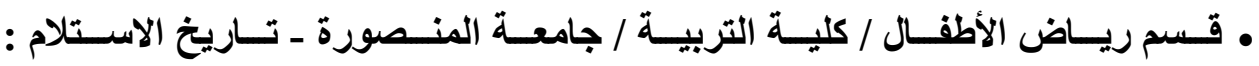
$. r+r / \varepsilon / r V$

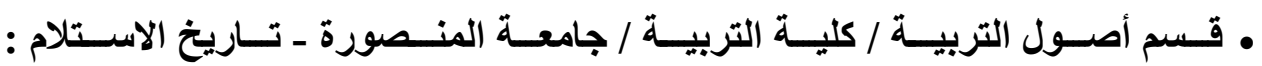
$.19 \vee \leqslant / 1 \cdot / V$

\section{المناصب الإدارية}

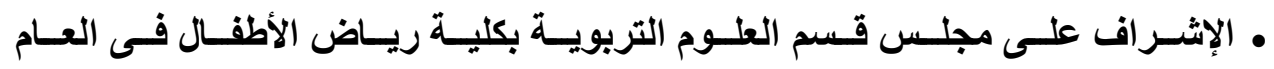

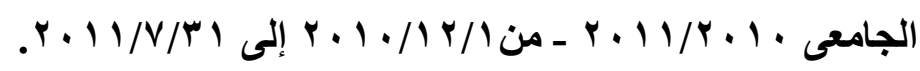

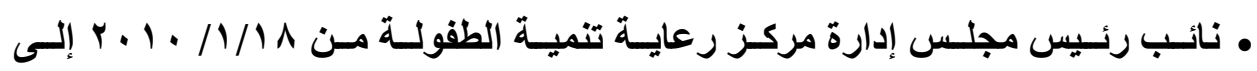

$$
r \cdot 11 / \mathrm{V} / \mathrm{r}
$$

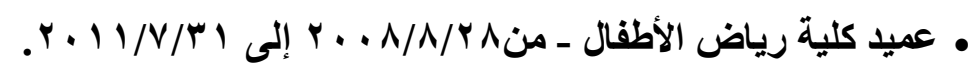

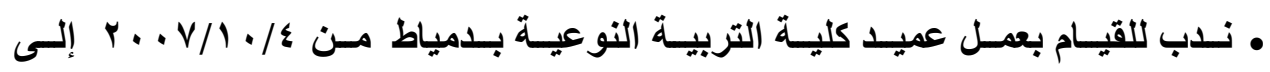
.r..人/V/rl

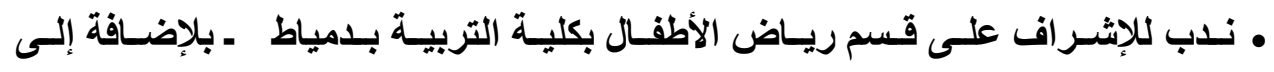

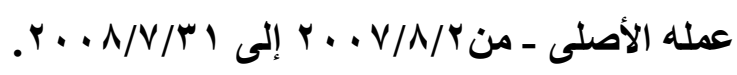

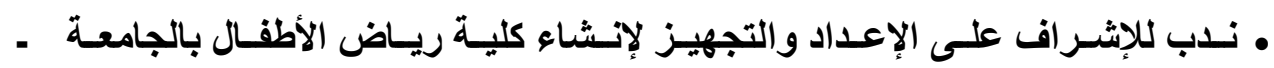

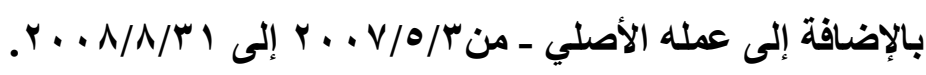

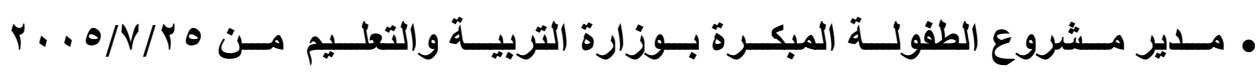
إلى

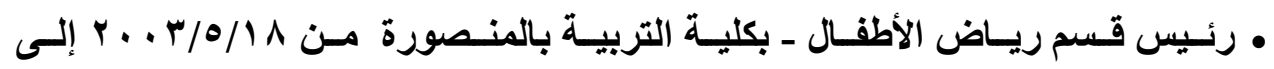
$. r \cdot \Lambda / 1 \cdot / \Lambda$

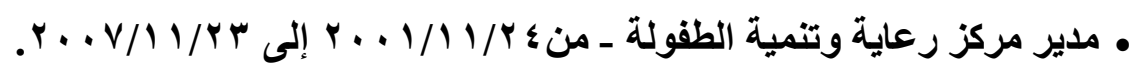




\section{الأعمال الإنشائية والتأسيسية}

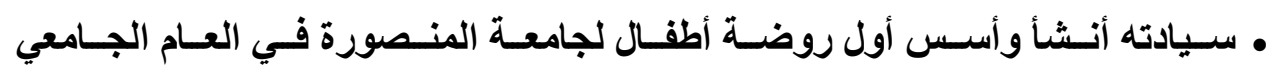

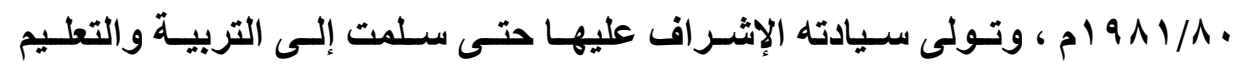

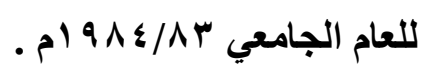

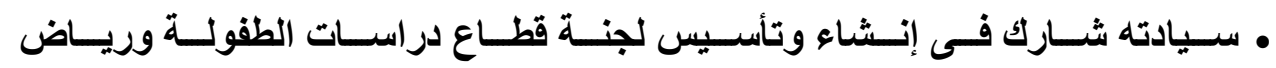

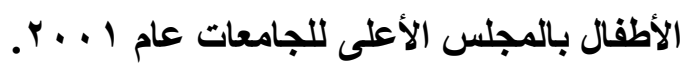

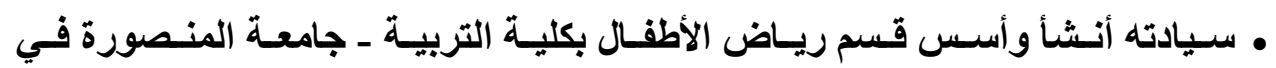

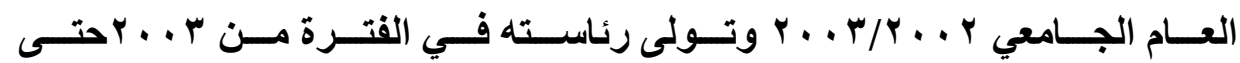

$$
\text { .r... }
$$

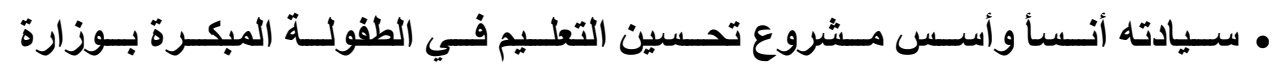

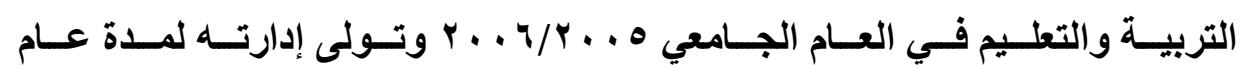

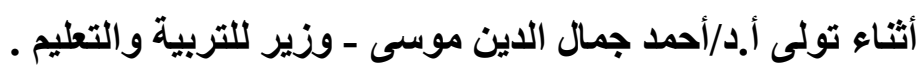

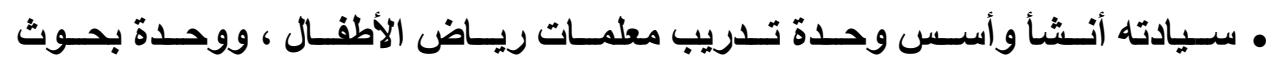

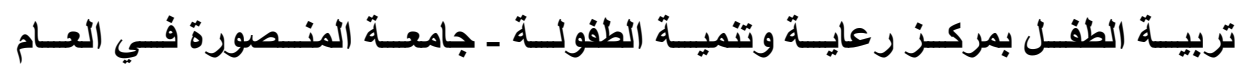

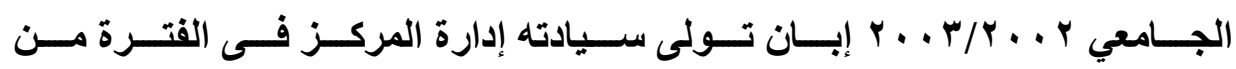

$$
\text { r...v vir... }
$$

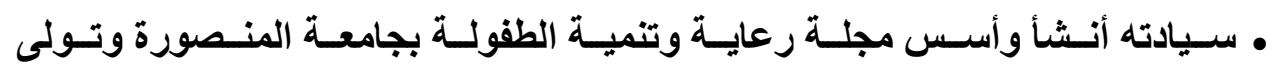

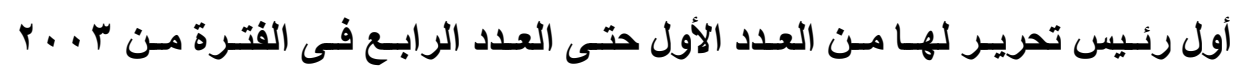

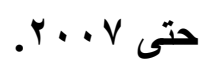

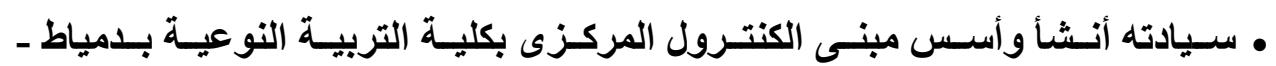

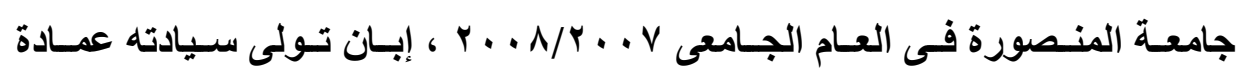

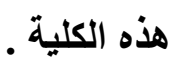




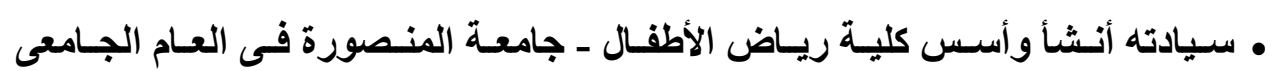

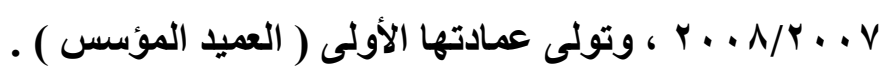

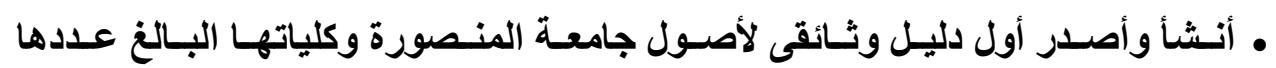

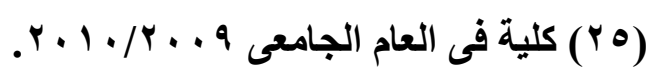

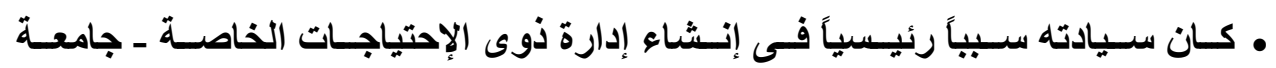

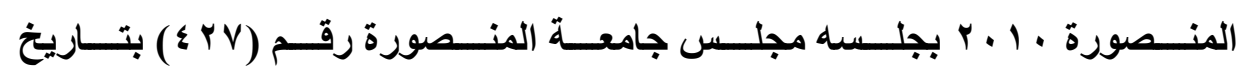

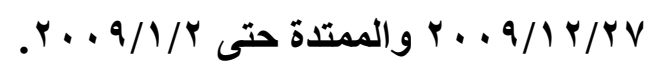

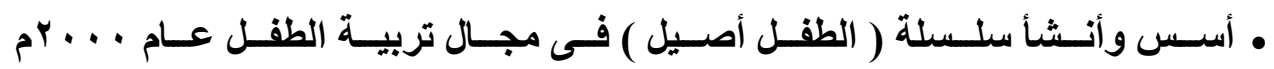

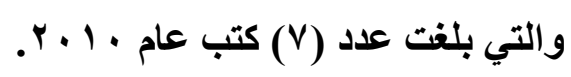

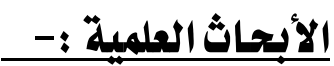

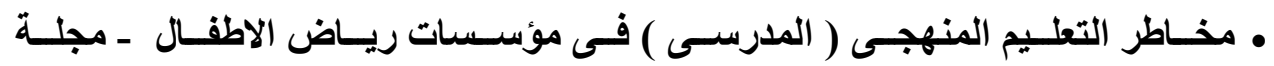

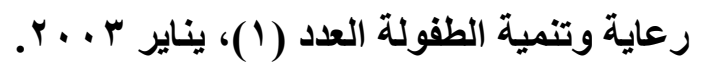

\section{M.Tolba prof.Gaber}

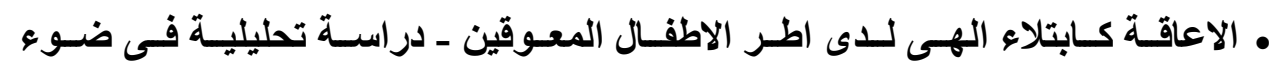

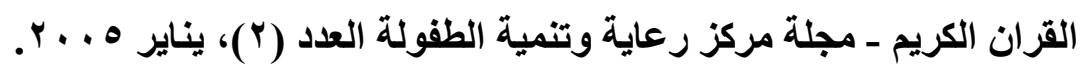

\section{M.Tolba prof.Gaber}

• ادمــاج ذوى الاحتياجـات الخاصــة فـى النظــام التعليمسى فـى مـصر ـ اغسطس

\section{M.Tolba prof.Gaber}

• ازمة التربويين فى مصر بين الواقع و المستقبل ـ ديسمبر ؛9 9 1.

\section{M.Tolba prof.Gaber}

$$
\text { • ازمة الوضع الاجتماعى فى التعليم الفنى فى مصر - يوليو ب9 } 9 \text { 1. }
$$

\section{M.Tolba prof.Gaber}


• ازمة التربويين فى مصر بين الواقع و المستقبل - ديسمبر \& 9 ا ـ .

M.Tolba prof.Gaber

$$
\text { • ازمة الوضع الاجتماعى فى التعليم الفنى فى مصر - يوليو ب9 } 99 \text { ـ }
$$

\section{M.Tolba prof.Gaber}

• البحث التربـوى فـى مـصر وعلاقتـه بالممارسـة التربويـة فـى نظــام التعلـيم ـ مـايو

M.Tolba prof.Gaber

$$
\text { • البحث التربوى واستشر اف مستقبل تربية/الطقل فى مصر - نوفمبر } 9 \text { ـ } 9 \text { ـ . }
$$

M.Tolba prof.Gaber

• التانيـث الكامـل لتربيـة الطفـل فـى دور الحضضانة وريـاض الاطفــال ـ مجلـة رعايـة

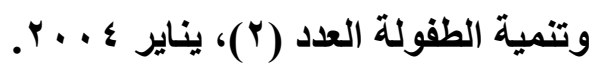

M.Tolba prof.Gaber

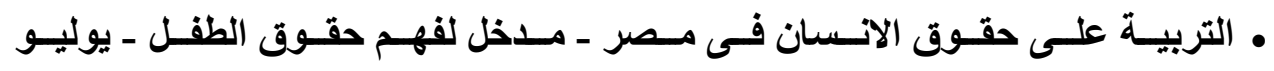

$$
\text { . } .0
$$

M.Tolba prof.Gaber

• التربيـة وحتميـة التغيير فـى المجتمـع المـصرى بـين دعـاة الحـوار وشـركاء الـوطن

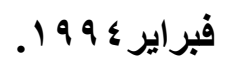

M.Tolba prof.Gaber

• التربيـة وعمليـة انتقـال الأطفــال المسـتجدين السى دور الــضانة وريـاض الأطفــال

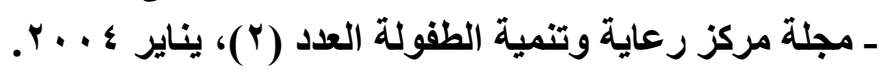

M.Tolba prof.Gaber

• التوجهــات الفكريـة فـى الخطــاب التربـوى لمجلــة التربيـة المعاصـرة ـ ديسـمبر

M.Tolba prof.Gaber 


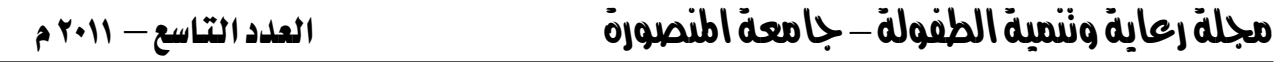

• تربيـة الأطفـال المعـوقين فـى ثقافـة المجتمـع العربـى بـين قيـود الاسـر ومطالـب

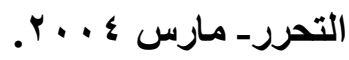

M.Tolba prof.Gaber

• توجهـات البحـث التربـوى فـى مجـال تربيـة الطفـل فـى كليـات التربيـة فى مسصر

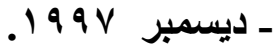

M.Tolba prof.Gaber

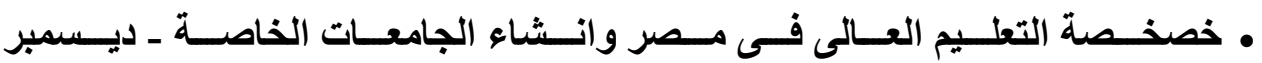
.1994

M.Tolba prof.Gaber

• سياسة تربية طقل ما قبل المدرسة فى مصر - يوليو ب 99 .

M.Tolba prof.Gaber

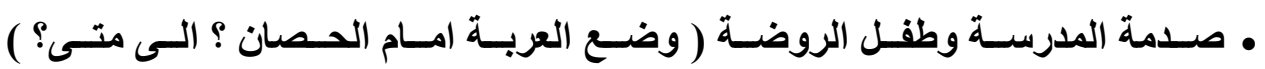

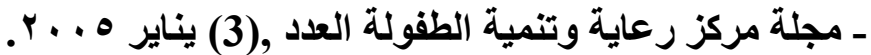

M.Tolba prof.Gaber

$$
\text { • متطلبات تربية الأطفال الموهوبين قبل المدرسة فى مصر ـ اكتوبر } 99 \text { V } 19
$$

M.Tolba prof.Gaber

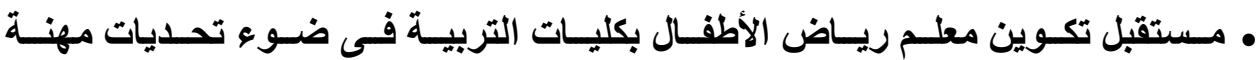

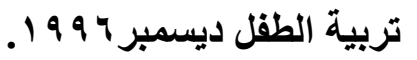

M.Tolba prof.Gaber

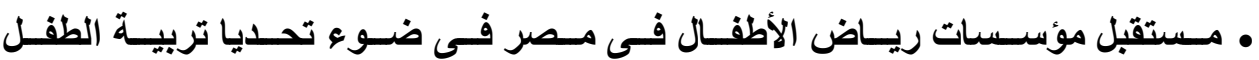

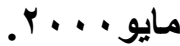

M.Tolba prof.Gaber

• نحو تربية ثقافية لمواجهة تحديات الغزو الثقافى المعاصر يوليو \&9 9 ـ. M.Tolba prof.Gaber

• نحو فلسفة لتربية القلب فى ضوء التصور الاسلامى ديسمبر ب9 9 1. M.Tolba prof.Gaber 
• خـصوصية تربيـة الطفـل الأطفــال الموهــوبين نموذجــا ) (أصـيل \&) بتــاريخ

$$
r . . v / T / 1
$$

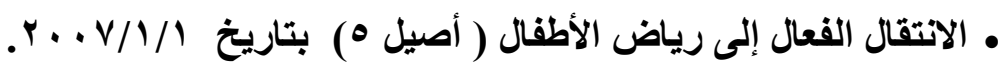

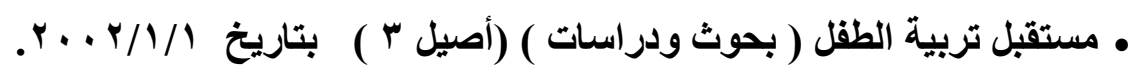

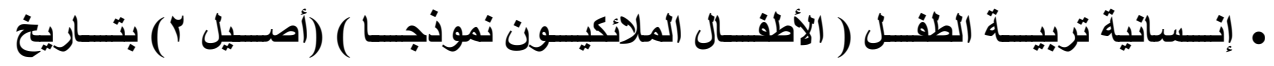

.r. r r/T/1

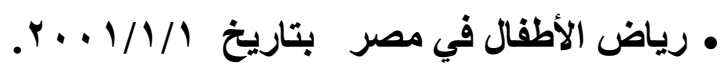

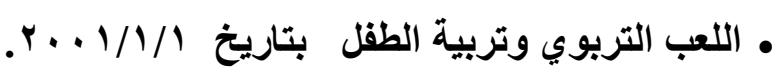

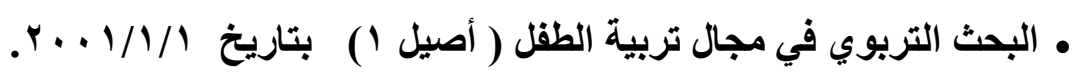

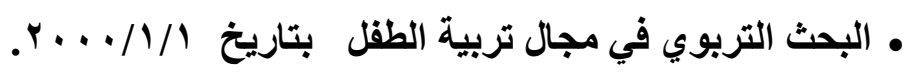

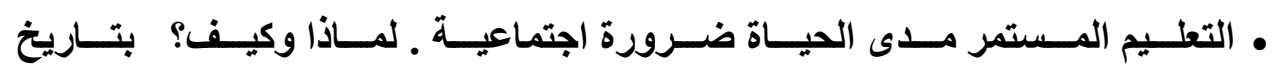

.r. . . I / /

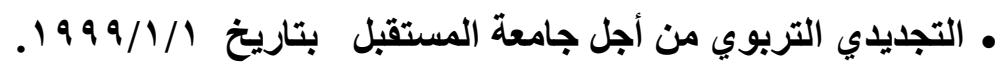

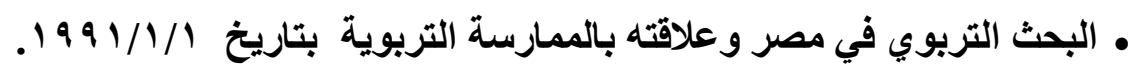

\section{الجيوائزوالتقليرات}

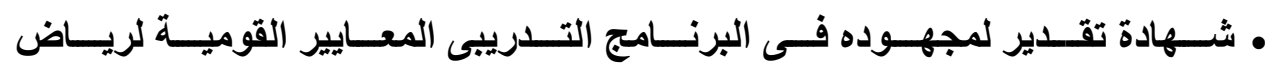

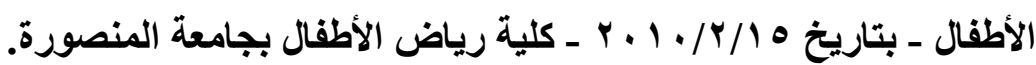

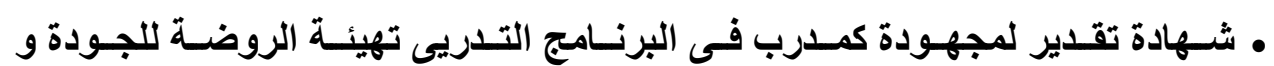

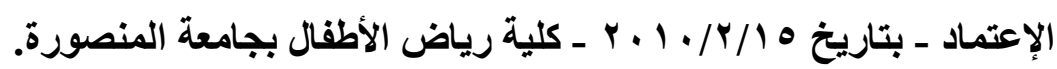

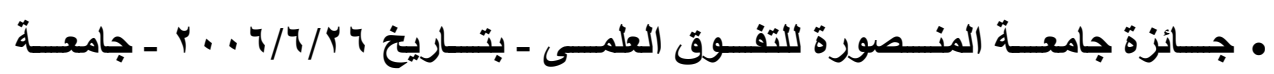

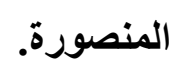




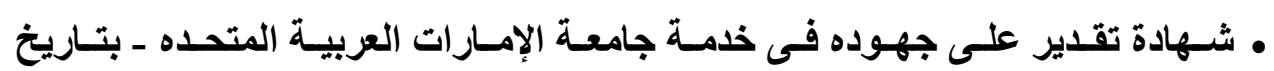

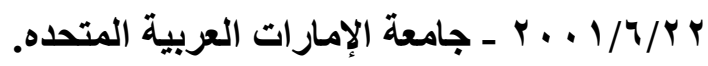

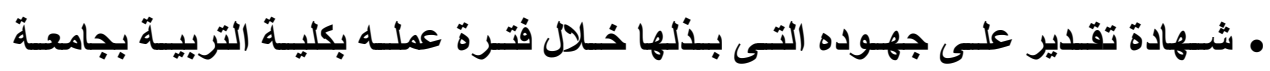

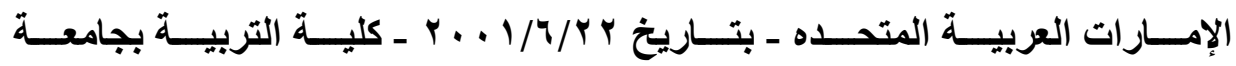

$$
\text { الإمارات العربية المتحدة. }
$$

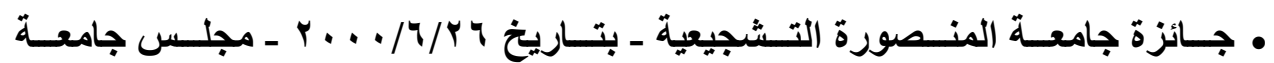

$$
\text { المنصورة. }
$$

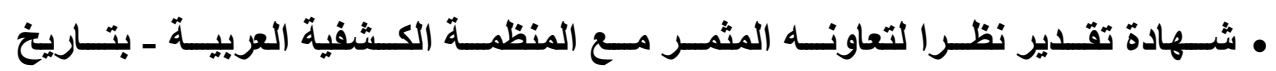

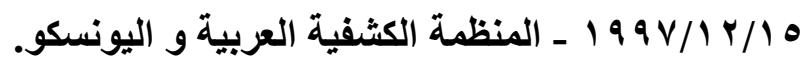

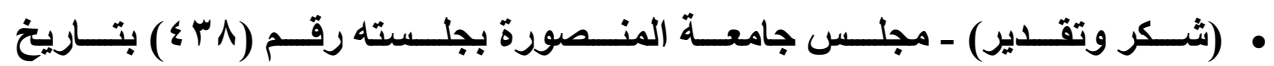

$$
r \cdot 1 \cdot / 1 / r \cdot-r \cdot 1 \cdot / 11 / r \text {. }
$$

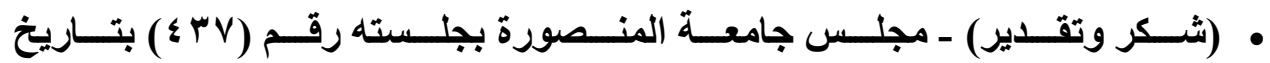

$$
r \cdot 1 \cdot / 1 \cdot / r^{\prime}-r \cdot 1 \cdot / 1 \cdot / \mu
$$

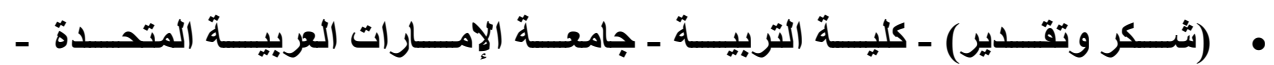

$$
r \cdot 1 \cdot / r / r r
$$

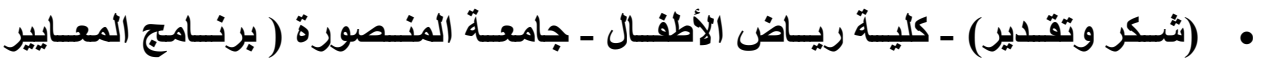

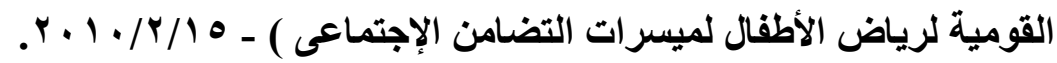

• (شـكر وتقـدير) - كليـة ريــاض الأطفــال - جامعـة المنـصورة ( برنــامج تهيئسة

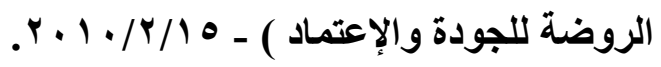

• (شـكر وتقــير) - كليـة ريـاض الأطفـال - جامعــة المنـصورة ( برنــامج المعسايير

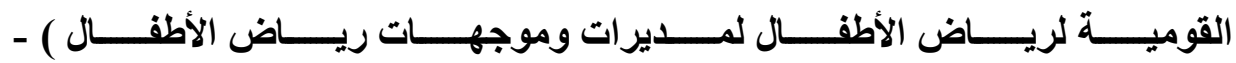

$$
r \cdot 1 \cdot / r / 10
$$

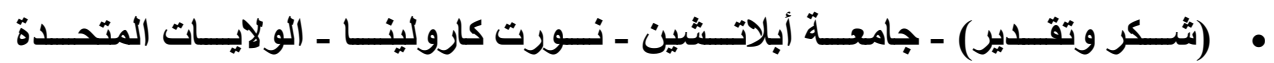

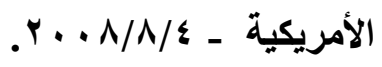


• شـكر وتقدير) - كليـة التربيـة النوعيـة ـ جامعـة المنـصورة ( فعاليـات المـؤتمر

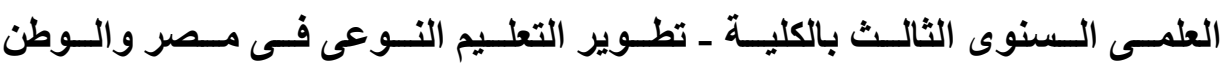

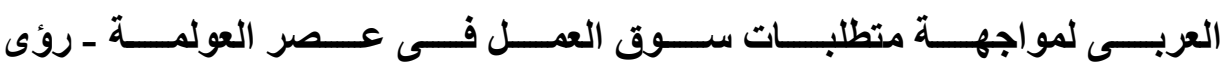

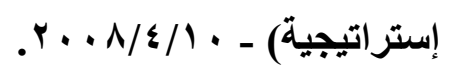

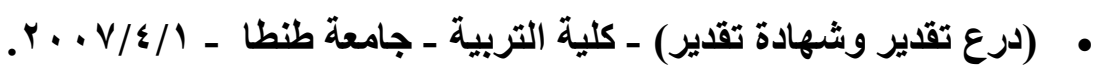

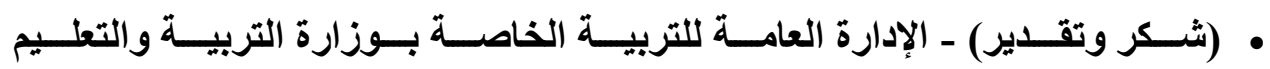

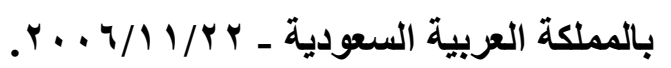

• (شـكر وتقـدير) - كليـة التربيـة التوعيـة ـ جامعـة المنـصورة ( فعاليـات المـؤتمر

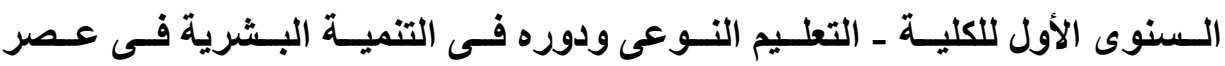

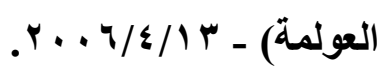

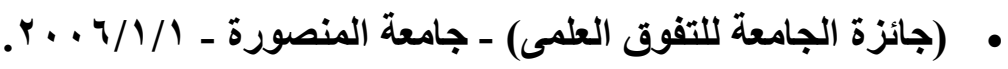

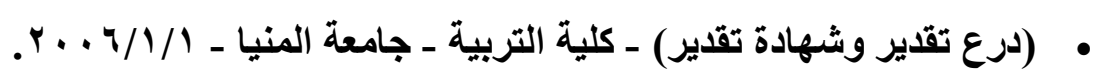

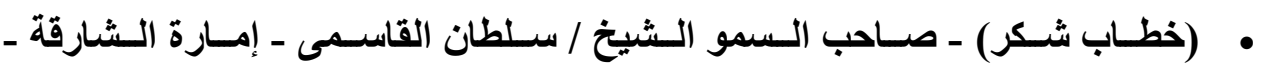

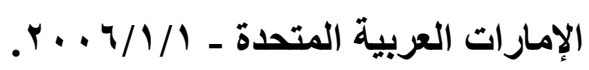

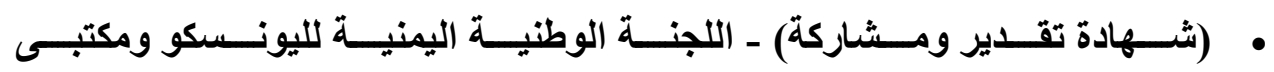

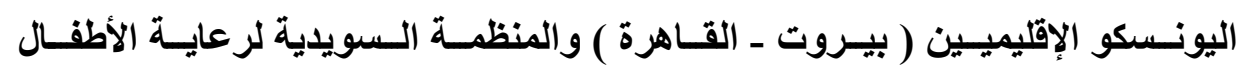

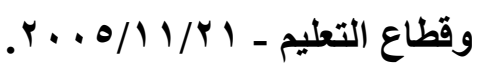

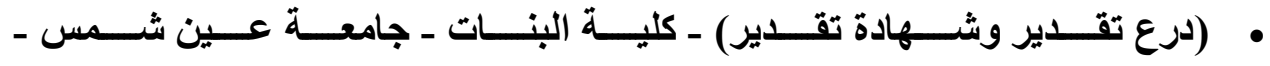

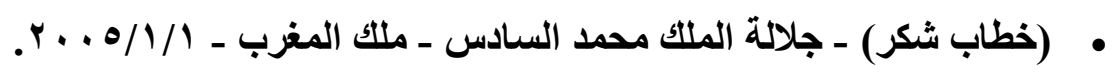

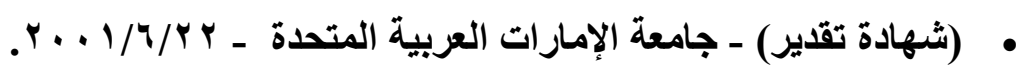

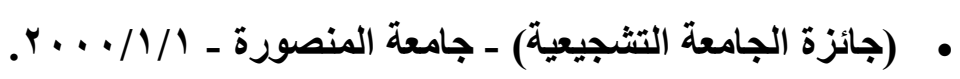

